\title{
Measuring the Electric Strength of Board Composite Materials and Insulators
}

\author{
R. Čech*, L. Buřval, P. Klaus \\ Institute of Progressive Technology for the Automotive Industry, Department of Foundry Engineering, \\ The Faculty of Metallurgy and Material Engineering, VŠB -TU of Ostrava, 17. listopadu 15, Ostrava - Poruba, \\ Czech republic \\ *Corresponding author: radim.cech@vsb.cz
}

DOI: 10.2478/V10158-011-0003-y

\begin{abstract}
This article contains the results of electric strength measuring of board composite materials and electrical insulators. It describes and briefly specifies the measured materials, i.e., the composites based on Glass, Kevlar and Carbon fiber. The composite electrical insulators are Kartit, Glasstextite and Textite. The measurement description shows the measurement system diagram and parameters of the used testing high-voltage source. The evaluation suggests the possibility of using composite materials as electromobiles' construction components which require specific electrical properties.
\end{abstract}

KEY WORDS: Electric strength, composite, insulators.

\section{INTRODUCTION}

The electric strength is a parameter that characterizes electric-insulating materials. Its value dimensioned use of electric insulators in practice. New requirements for automobile construction parts emerged during the electromobile development in the research laboratories of the Institute of Progressive Technology for the Automotive Industry. This is particularly applied to the electromobile chassis. Function parts and battery boxes are consequently connected to the chassis. The battery boxes contain power contacts with monitoring and control elements (BMS). To achieve a higher consistency and lower automobile weight, it is important to simplify and merge certain construction elements. In our case, it is the unification of the chassis and battery boxes into one function unit.

Knowledge of the electric strength of the above-mentioned materials is therefore important for determining the safety of electric vehicle components. Understanding a material's electric characteristics is an important factor in the production of electric devices and electromobile development as well. The reason is to reach the maximum possible safety for electromobile operation.

\section{THEORETICAL ANALYSIS OF THE EXPERIMENT}

\subsection{Definition of Electric Strength}

Electric strength is the critical size of the electric field intensity in which materials lose their insulating or dielectric capability. Solid materials are permanently damaged by an electric breakdown. 
The essence of the electric breakdown is an intense increase in electric conductivity in the material. It is caused by a sudden increase in the concentration of free charge carriers. The electric breakdown proceeds to the electric arc until source shutdown. The damage range depends on the arc action duration, surrounding atmospheric conditions, specimens' material and the value of the passing current. We make a distinction between two electric breakdown types, thermic and purely electric.

The thermal breakdown of solid insulators is evoked by a sudden development of heat evoking an unlimited temperature rise until the critical moment when the insulator is thermally damaged in a particular local place and its insulating capacity drops significantly. Dielectric losses are the source of the heat. Conductivity and loss factor increase by heating the material. If conditions for reliable heat removal to the surroundings are created, the temperature increase stops at a certain level and no breakdown appears.

Dielectric losses can be physically divided into:

- Conductance losses occur in all insulators because they all contain a certain number of free electrical charges and their movement at AC or DC voltage is linked with the transformation of electrical energy into heat.

- Polarization losses are caused by a delay-bound movement of electrical charges for changing the size of the electrical field intensity. Here some of the energy obtained from an electrical field stays in the form of kinetic energy and transfers it to the neutral particles of material which are causing heat generation.

- Ionization losses occur in the gas cavities of solid insulators when the voltage is higher than the gas ionization voltage.

- Pure electric breakdown is the result of the interaction of electrons occurring in the material with the present electrical field. Electrons gain energy from the electrical field during their free electron path. This energy is transferred to the material when the material brakes the movement of the electrons. If this process of energy increase is higher than the energy decrement, a pure electric breakdown appears. The size of the electrical field Ep intensity in this type of breakdown is independent of the insulator thickness, electrode shape, and also on the voltage waveform over time. This depends especially on the material's structure and atomic composition.

In practice, the electric and thermal breakdowns can occur simultaneously because conditions are created for both the above-described electron process and sufficient heat generation as a consequence of dielectric losses.
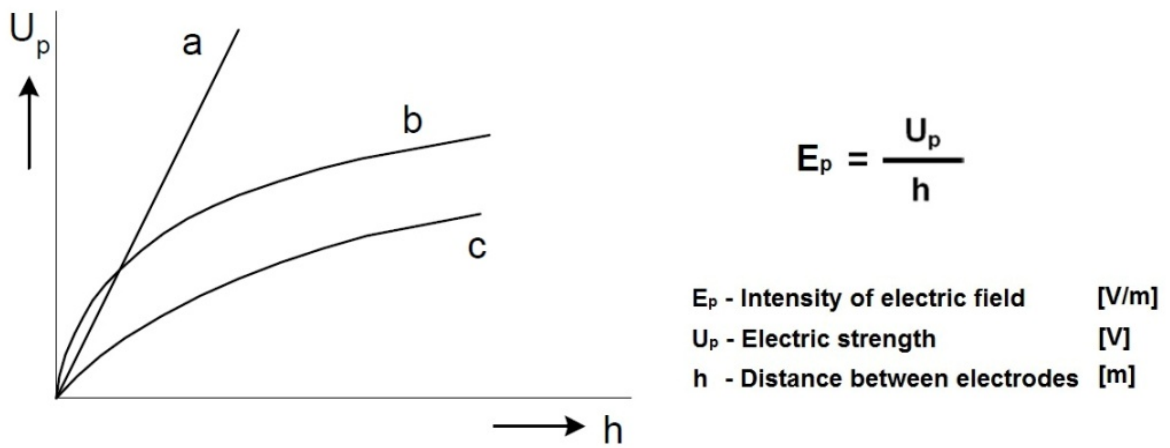

Figure1: Dependence $U p=f(h)$, formula for calculation Ep.

a) purely electric breakdown, b) thermal breakdown, c) participation of both types of breakdown. 


\section{DESCRIPTION OF THE MEASURING DEVICE}

The measuring device was proposed and constructed specially for this experiment. It was based on knowledge provided by the Czech technical standard CSN EN 60243-2 The Electric Strength of Insulation Materials - Experimental Methods - Part 2: Additional requirements for direct tension testing.

\subsection{Measuring Stand with High-Speed Camera}

The measuring stand was constructed with respect to the properties and parameters of the experimental specimens and the used electrodes. For the accurate detection of the breakdown, we used high-speed camera recording (see fig. 2), which was used for dynamic processes.

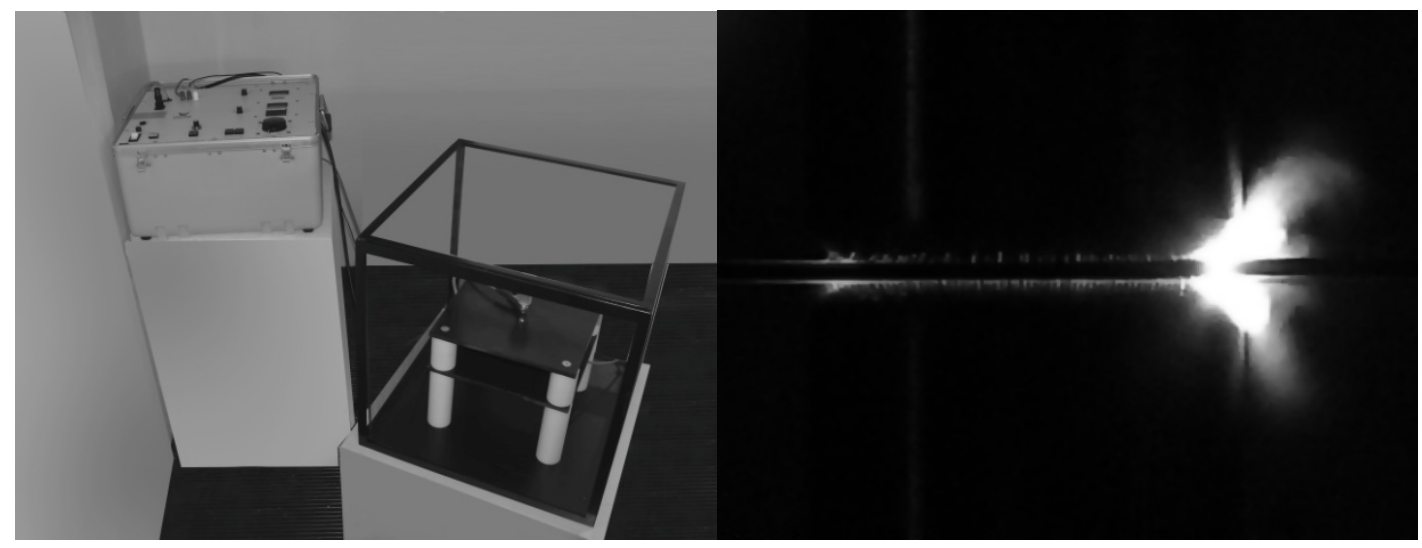

Figure 2: High voltage source and electric strength measuring stand in the left picture, a high speed camera shot of material breakdown in the right picture.

3.2 High Voltage Source - Wiring Scheme

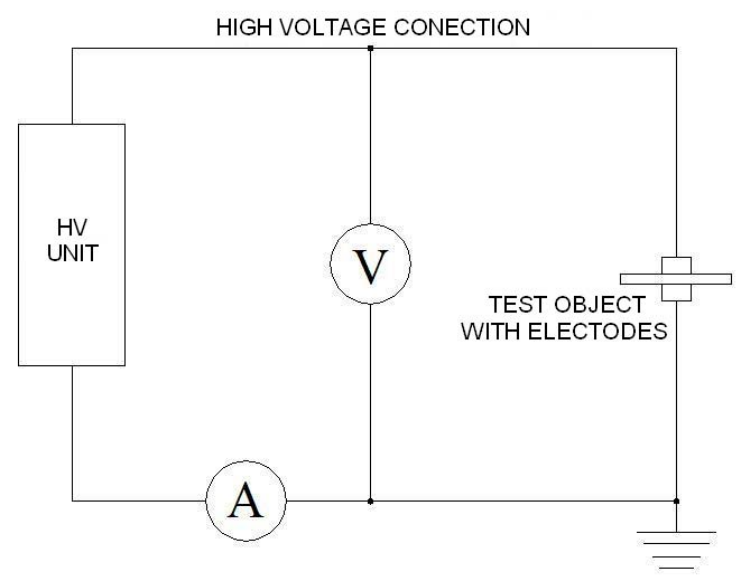

DETAIL TEST OBJECT WITHELECTRODES

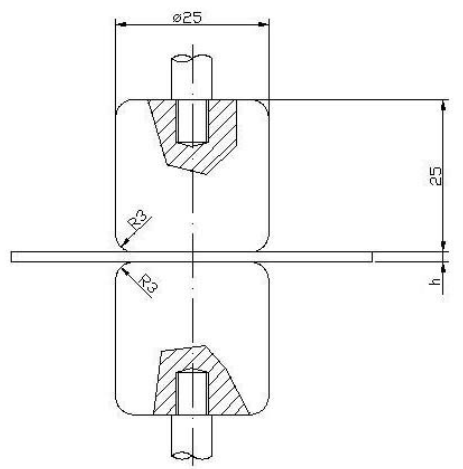

Figure 3: Simplified electrical diagram of measuring stand. 


\begin{tabular}{|c|c|}
\hline \multicolumn{2}{|c|}{ CONSTRUCTION COMPOSITE MATERIALS } \\
\hline FIBERGLASS & $\begin{array}{l}\text { Composition: Epoxide resin LHI } 60 \text {, } \\
\text { hardener H534, } 5 \text { x glass fabric } 200 \\
\mathrm{~g} / \mathrm{m}^{2} \text { cloth. (Dimension } 200 \times 200 \mathrm{~mm} \text { ) }\end{array}$ \\
\hline KEVLAR & $\begin{array}{l}\text { Composition: Epoxide resin LHI60, } \\
\text { hardener H534, } 5 \text { x kevlar fabric } 173 \\
\mathrm{~g} / \mathrm{m}^{2} \text {. } \\
\text { (Dimension } 200 \times 200 \mathrm{~mm} \text { ) }\end{array}$ \\
\hline $\begin{array}{l}\text { FIBERGLASS/ } \\
\text { KEVLAR }\end{array}$ & $\begin{array}{l}\text { Composition: Epoxide resin } \mathrm{LHI} 60 \text {, } \\
\text { hardener H534, } 2 \text { x glass fabric } \\
200 \mathrm{~g} / \mathrm{m}^{2} \text { Cloth, } 3 \text { kevlar fabric } 173 \\
\mathrm{~g} / \mathrm{m}^{2} \text {. (Dimension } 200 \times 200 \mathrm{~mm} \text { ) }\end{array}$ \\
\hline CARBON & $\begin{array}{l}\text { Composition: Epoxide resin } \mathrm{LHI} 60 \text {, } \\
\text { hardener H534, I x carbon fabric twill } \\
200 \mathrm{~g} / \mathrm{m}^{2}, 2 \times \text { carbon fabric } 300 \mathrm{~g} / \mathrm{m}^{2} \\
\text { biaxial. (Dimension } 200 \times 200 \mathrm{~mm} \text { ) }\end{array}$ \\
\hline $\begin{array}{l}\text { KEVLAR/ } \\
\text { CARBON }\end{array}$ & $\begin{array}{l}\text { Composition: Epoxide resin LHI60, } \\
\text { hardener H534, } 5 \times \text { fabric kevlar- } \\
\text { carbon } 165 \mathrm{~g} / \mathrm{m}^{2} \text { cloth. (Dimension } \\
200 \times 200 \mathrm{~mm} \text { ) }\end{array}$ \\
\hline
\end{tabular}

\section{ELECTRIC-ISOLATION COMPOSITE MATERIALS}

\begin{tabular}{|c|l|l|}
\hline KARTIT & & $\begin{array}{l}\text { Composition: Cellulose paper as } \\
\text { support, modificate phenolic } \\
\text { bitumen as bond. (Dimension } \\
200 \times 200 \mathrm{~mm})\end{array}$ \\
\hline TEXTITE & & $\begin{array}{l}\text { Composition: Cotton cloth as } \\
\text { support, phenolic bitumen as bond. } \\
\text { (Dimension 200x200mm) }\end{array}$ \\
\hline GLASSTEXTITE & & $\begin{array}{l}\text { Composition: Modified glass fabric as } \\
\text { support, epoxide bitumen as bond. } \\
\text { (Dimension 200x200mm) }\end{array}$ \\
\hline
\end{tabular}




\section{RESULTS AND DISCUSSION}

Tab. 1 Table of measured and calculated experimental data.

\begin{tabular}{|c|c|c|c|c|c|c|}
\hline $\begin{array}{l}\text { Identification } \\
\text { of the } \\
\text { material }\end{array}$ & $\begin{array}{l}\text { Sample } \\
\text { number }\end{array}$ & $\begin{array}{l}\text { Electric } \\
\text { strength } \\
{[\mathrm{kV} / \mathrm{mm}]}\end{array}$ & $\begin{array}{l}\text { The } \\
\text { thickness } \\
\text { of the } \\
\text { sample at } \\
\text { the } \\
\text { Breakdown } \\
\text { [mm] } \\
\end{array}$ & $\begin{array}{l}\text { Breakdown } \\
\text { voltage } \\
{[\mathrm{kV}]}\end{array}$ & $\begin{array}{l}\text { The } \\
\text { median } \\
\text { value of } \\
\text { electric } \\
\text { strength } \\
\text { [kV/mm] }\end{array}$ & $\begin{array}{l}\text { Maximum } \\
\text { measurement } \\
\text { error } \\
{[\mathrm{kV} / \mathrm{mm}]}\end{array}$ \\
\hline \multirow[t]{5}{*}{ Fiberglass } & S 1 & 50,77 & 1,31 & 66,51 & \multirow{5}{*}{49,96} & \multirow{5}{*}{ $\pm 0,98$} \\
\hline & S 2 & 49,25 & 1,15 & 56,63 & & \\
\hline & S 3 & 50,53 & 1,23 & 62,15 & & \\
\hline & S 4 & 49,64 & 1,27 & 63,05 & & \\
\hline & S 5 & 49,62 & 1,24 & 61,53 & & \\
\hline \multirow[t]{5}{*}{ Kevlar } & SK 1 & 44,06 & 1,42 & 62,57 & \multirow{5}{*}{44,54} & \multirow{5}{*}{ $\pm 1,32$} \\
\hline & SK 2 & 45,97 & 1,45 & 66,65 & & \\
\hline & SK 3 & 43,67 & 1,42 & 62,02 & & \\
\hline & SK 4 & 44,32 & 1,42 & 62,94 & & \\
\hline & SK 5 & 44,69 & 1,43 & 63,91 & & \\
\hline \multirow{5}{*}{$\begin{array}{l}\text { Fiberglass/ } \\
\text { Kevlar }\end{array}$} & K 1 & 46,32 & 1,39 & 64,39 & \multirow{5}{*}{46,43} & \multirow{5}{*}{ $\pm 0,58$} \\
\hline & $\mathrm{K} 2$ & 46,38 & 1,37 & 63,54 & & \\
\hline & K3 & 45,87 & 1,38 & 63,30 & & \\
\hline & K4 & 46,88 & 1,40 & 65,63 & & \\
\hline & K5 & 46,71 & 1,36 & 63,52 & & \\
\hline \multirow[t]{5}{*}{ Glasstextite } & ST 1 & 71,94 & 1,15 & 82,73 & \multirow{5}{*}{70,26} & \multirow{5}{*}{ $\pm 1,88$} \\
\hline & ST 2 & 70,29 & 1,14 & 80,13 & & \\
\hline & ST 3 & 70,93 & 1,18 & 83,70 & & \\
\hline & ST 4 & 69,33 & 1,11 & 76,96 & & \\
\hline & ST 5 & 68,81 & 1,18 & 81,20 & & \\
\hline \multirow{5}{*}{$\begin{array}{l}\text { Kartit } \\
\text { (Pertinax) }\end{array}$} & $0,5 \mathrm{KT} 1$ & 27,36 & 0,53 & 14,50 & \multirow{5}{*}{28,60} & \multirow{5}{*}{ $\pm 1,55$} \\
\hline & $0,5 \mathrm{KT} 2$ & 30,00 & 0,52 & 15,60 & & \\
\hline & $0,5 \mathrm{KT} 3$ & 28,27 & 0,52 & 14,70 & & \\
\hline & $0,5 \mathrm{KT} 4$ & 29,25 & 0,53 & 15,50 & & \\
\hline & $0,5 \mathrm{KT} 5$ & 28,11 & 0,53 & 14,90 & & \\
\hline \multirow[t]{5}{*}{ Textite } & T 1 & 27,19 & 0,89 & 24,20 & \multirow{5}{*}{27,33} & \multirow{5}{*}{ $\pm 0,55$} \\
\hline & T 2 & 27,42 & 0,92 & 25,22 & & \\
\hline & T 3 & 26,85 & 0,93 & 24,97 & & \\
\hline & T 4 & 27,30 & 0,91 & 24,85 & & \\
\hline & T 5 & 27,87 & 0,91 & 25,36 & & \\
\hline \multirow[t]{5}{*}{ Carbon } & $\mathrm{U} 1$ & 0,00 & 1,52 & 0,00 & \multirow{5}{*}{0,00} & \multirow{5}{*}{ \pm 0} \\
\hline & $\mathrm{U} 2$ & 0,00 & 1,47 & 0,00 & & \\
\hline & U 3 & 0,00 & 1,48 & 0,00 & & \\
\hline & U 4 & 0,00 & 1,65 & 0,00 & & \\
\hline & U 5 & 0,00 & 1,58 & 0,00 & & \\
\hline \multirow{5}{*}{ Kevlar/Carbon } & KU 1 & 0,00 & 1,57 & 0,00 & \multirow{5}{*}{0,00} & \multirow{5}{*}{ \pm 0} \\
\hline & KU 2 & 0,00 & 1,52 & 0,00 & & \\
\hline & KU 3 & 0,00 & 1,50 & 0,00 & & \\
\hline & KU 4 & 0,00 & 1,55 & 0,00 & & \\
\hline & KU 5 & 0,00 & 1,50 & 0,00 & & \\
\hline
\end{tabular}




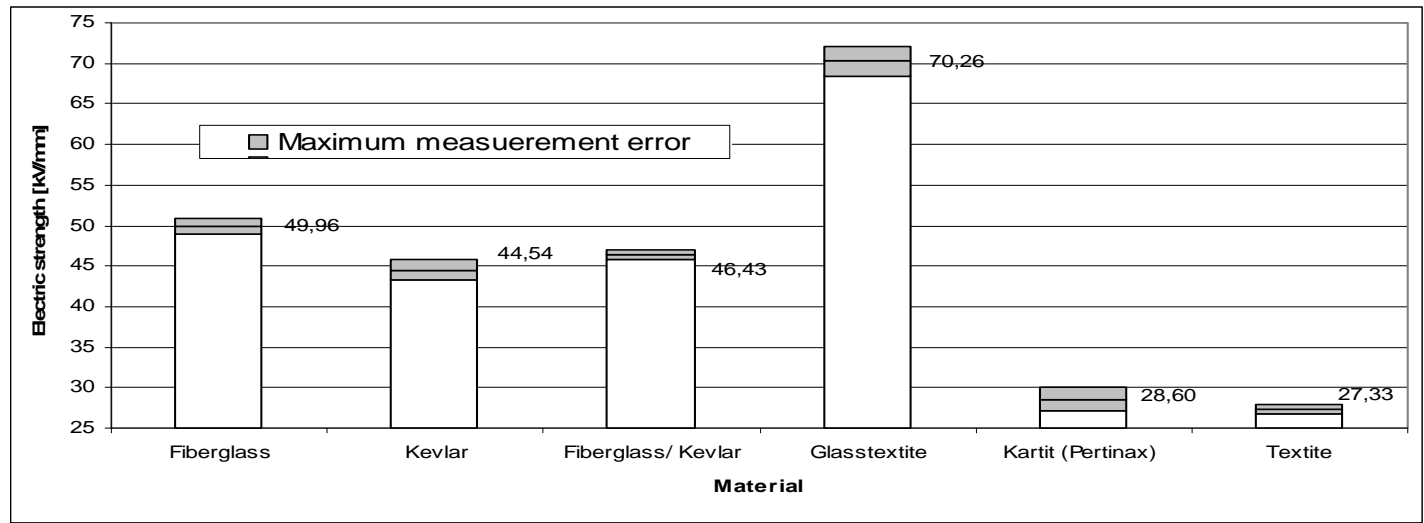

Figure 4: Electric strength diagram.

The results of the experiment lead to several findings. The acceptable materials for the electrical insulating construction parts of the electromobile are the composites Fiberglass, Fiberglass/Kevlar, and Kevlar. These materials have more than 100 percent higher electric strength than the electrical insulation materials Kartit or Textite. Carbon-based composites seem less suitable for non-conducting structures and components. Carbon fiber in composites creates a non-homogenous field of conductible canals. The conductivity of composites with a carbon component is caused by defects in the surface layer of resin and the presence of frayed ends of carbon fibers. These frayed ends extend to the surface of the composite. For this reason, carbon-based composites cannot be recommended for separating strong electrical circuits from the environment.

A significant finding is the analysis of the difference in the electric strength of Fiberglass and Glasstextite. Glasstextite's electric strength is $30 \%$ higher. These materials have a very similar composition and differ especially in the production technology. Glasstextite is created using an industrial technique. The Fiberglass manual creation technology causes the formation of fine gaseous cavities in the composite volume. Ionization occurs in these fine gaseous cavities with a high electrical field. The ionization causes the chemical-thermal transformation of the gaseous state and, in some cases, cavities split and the material is damaged by the outburst of ionized gas. For this reason there is a breakdown of the material at a lower voltage level.

The results were achieved thanks to the financial support of the specific research SV 6320011.

\section{REFERENCES}

Meranie elektrickej pevnosti izolantov [online., cit. 2010-11-03]. $<$ http://www.matnet.sav.sk/index.php?ID=360>

Hassenteufel, J., 1971. Elektrotechnické materiály. Bratislava: ALFA.

Britton, J., 2008. Dc dielectric test set-400P. Maryland: Phenix Technologies, Inc, vol.5

Tomčík, P., Trojan, R. 2007. Využití vysokorychlostních kamer a kamer s vysokým rozlišením při výuce. In Konference s mezinárodní účastí TechMat 07, Perspektivní technologie a materiály pro technické aplikace, Sborník přednášek : 15. 11. 2007 Svitavy : Univerzita Pardubice, Dopravní fakulta Jana Pernera, 2007, s.71-75.ISBN 978-80-7395-013-2. 